\title{
Women Voters in Indian Democracy A Silent Revolution
}

MUDIT KAPOOR, SHAMIKA RAVI

An analysis of the political participation of women by comparing the turnout of women voters to men in all the state elections from 1962 till 2012 reveals a steady and sharp decline in the gender bias in voting over time. This phenomenon is seen across all the states, including the traditionally "backward" states of north India.
Mudit Kapoor (Mudit_kapoor@isb.edu) and Shamika Ravi (Shamika_ravi@isb.edu) are at the Indian School of Business, Hyderabad.
$\mathrm{T}$ The persistence of gender inequality which is embodied in "missing women", a concept developed by Sen $(1990,1992)$, is a common phenomenon in low-income countries and is suspiciously high in countries such as India and China. Through a political context, our study aims to contribute to the broader literature and understanding of gender inequality.

More specifically, in this article, we study the gender bias in political participation by analysing women voter turnout in Indian democracy from 1962 till 2012 and discover a silent revolution. The main finding of our analysis is a steady and a sharp decline in the gender bias in voting over time. In particular, we find that the sex ratio of voters which is defined as the number of women voters to every 1,0oo men voters, increased very impressively from 715 in the 1960s to 883 in the 200os. We also find that this phenomenon of declining gender bias in voting is across all the states, including the traditionally backward "BIMARU" states of Bihar, Madhya Pradesh (MP), Rajasthan and Uttar Pradesh (UP). On decomposing the data further, we discover that this decline in gender bias of voters is solely driven by the dramatic increase in women participation in the elections since the 1990s, while men participation has remained unchanged.

The right to equality in voting is a basic human right in liberal democracy. Women enjoy this right to equality in voting, and by casting a vote they make a formal expression of their individual choice of political parties, representatives or of broad policies. The fact that more women are voluntarily exercising their constitutional right of adult suffrage across all states in India is testimony to the rise of self-empowerment of women to secure their fundamental right to freedom of expression. This is an extraordinary achievement in the world's largest democracy with 717 million voters of which 342 million voters are women.

Existing literature has documented a significant gender gap in various sectors including health, labour market opportunities, education and political representation. Anderson and Ray (2010) provide a decomposition of missing women by age and cause of death, and their findings suggest that excess female mortality is a universal phenomenon and should not be attributed merely to parental preferences. Duflo (2012) provides an excellent overview of the literature by reviewing the relationship between gender inequality and economic development. In contrast to existing literature which finds stark persistence in gender inequality over time in various outcomes, we report a more positive phenomenon of sharply declining gender bias in political participation measured by voter turnout. We document the growing political empowerment of women voters in India. The reason why this is an important development is because it is not an outcome of any specific top-down policy intervention to raise voter turnout of women, but is driven over time by the voluntary act of self-empowerment of women.

This article also differs from the existing research on women and politics in a fundamental way. While previous works have focused on women as policymakers, our emphasis is on women as voters in a political system. This is a critical area of research as women voters comprise a significant share in any election within a representative democracy.

For our analysis, we use constituencylevel data from the Election Commission of India (ECI). We analyse all state assembly elections held from 1962 till 2012, for 16 large states. These 16 states together represent more than $93 \%$ of the total electors in India. This is a rich data set which has been used by earlier papers that have explored women's political participation and crime 
(Iyer et al 2012), how voters respond to criminal charges of candidates (Dutta and Gupta 2012) and relationship of growth to election outcomes in India (Gupta and Panagariya 2012).

The rest of the article is organised in the following manner: we briefly describe ECI data in Section 1. Within the data section, we also describe the construction of variables of interest that we analyse from the data. The results are analysed in Section 2 where we highlight the consistent trends of reducing gender gap in voter turnout in all states of India over the last five decades. We discuss and conclude our findings in Section 3.

\section{Data}

The first general election in India was held in 1951-52 and so far 17 elections to the House of the People have been held. At present there are 543 members in the Lok Sabha. The Election Commission is a permanent constitutional body that was established in 1950.

The EcI collects and documents election data for each and every parliamentary and the state assembly constituency. For each constituency it reports data on the total number of electors and voters which are segregated by gender, the name and gender of each candidate contesting the election, party affiliation of each contestant and if the candidate is not affiliated to any party then the candidate is categorised as an independent, and the total number of votes secured by each candidate in the election. This data is available for every general election held in the parliamentary and the state assembly constituency from 1951 till 2012.

For our analysis we use data at the constituency level for the state assembly elections held for 16 large states from 1962 till 2012. These 16 large states represent more than $93 \%$ of the total electors in India. Next we describe the construction of the variables of interest using the data at the constituency level.

sex ratio of voters ${ }_{\text {st }}$

$$
=\left(\frac{\sum_{i=1}^{N s} \text { female voters }_{i t}}{\sum_{i=1}^{N s} \text { male voters }_{i t}}\right) * 1000
$$

sex ratio of electors

$$
=\left(\frac{\sum_{i=1}^{N s} \text { female electors }_{i t}}{\sum_{i=1}^{N s} \text { male electors }_{i t}}\right) * 1000
$$

female poll percentage $\mathrm{st}_{\mathrm{st}}$

$$
=\left(\frac{\sum_{i=1}^{N s} \text { female voters }_{i t}}{\sum_{i=1}^{N s} \text { female electors }_{i t}}\right) * 100
$$

male poll percentage ${ }_{\text {st }}$

$$
=\left(\frac{\sum_{\mathrm{i}=1}^{\mathrm{Ns}} \text { male voters }_{\mathrm{it}}}{\sum_{\mathrm{i}=1}^{\mathrm{Ns}} \text { male electors }_{\mathrm{it}}}\right) * 100
$$

where $s$ is the state, $t$ is the year in which the election is held for the state assembly, $i$ is the assembly constituency in state $s$, and $N s$ is the total number of assembly constituencies in state $s$. In Table 1 we summarise the years in which the assembly elections were held in each of the big 16 states in India.

\section{Table 1: States and the Election Years}

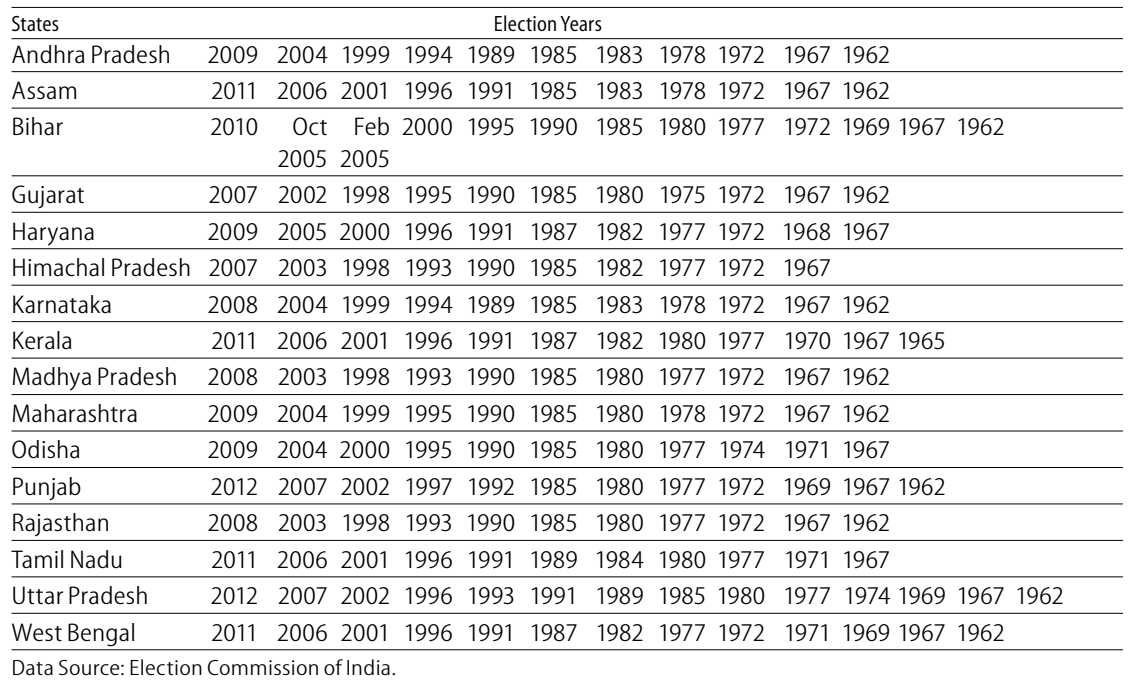

\section{Results}

The first set of results are summarised in Tables 2a and 2b. Before we explain the results it is important to describe how we construct the average sex ratio of voters for every state for the elections

\section{Table 2a: Average Sex Ratio of the Voters}

\begin{tabular}{lccccc}
\hline States & $1960 s$ & $1970 s$ & $1980 s$ & $1990 s$ & $2000 s$ \\
\hline Andhra Pradesh & 886 & 910 & 917 & 924 & 971 \\
\hline Assam & 620 & 716 & 780 & 868 & 896 \\
\hline Bihar & 567 & 573 & 625 & 701 & 783 \\
\hline Gujarat & 786 & 824 & 799 & 824 & 853 \\
\hline Haryana & 807 & 806 & 806 & 815 & 810 \\
\hline Himachal Pradesh & 675 & 802 & 957 & 970 & 1,029 \\
\hline Karnataka & 797 & 843 & 856 & 886 & 913 \\
\hline Kerala & 981 & 1,034 & 1,017 & 1,027 & 1,046 \\
\hline Madhya Pradesh & 558 & 677 & 677 & 730 & 804 \\
\hline Maharashtra & 794 & 853 & 823 & 859 & 855 \\
\hline Odisha & 572 & 639 & 679 & 802 & 866 \\
\hline Punjab & 777 & 810 & 810 & 793 & 904 \\
\hline Rajasthan & 603 & 745 & 735 & 760 & 861 \\
\hline Tamil Nadu & 949 & 917 & 926 & 923 & 961 \\
\hline Uttar Pradesh & 614 & 667 & 660 & 671 & 761 \\
\hline West Bengal & 670 & 707 & 831 & 880 & 886 \\
\hline Source: Authors' calculations from ECI data. & &
\end{tabular}

held in each of the decades from the 1960s till the 200os. We illustrate this with the help of an example. In up in the decade of 1960 s, three state elections were held in 1962, 1967 and 1969 and in each of these elections the sex ratio of the voters was 538, 675, and 629 respectively. So we compute the simple mean of these three sex ratios of the voters which is 614 and define that as the average sex ratio of the voters in the 1960 s in UP. For each state we do a similar computation for all the decades. Our results reveal a very interesting pattern - for every state from the 1960 s to the 2000 s there has been a significant improvement in the sex ratio of the voters; however, in Haryana and Tamil Nadu (TN) the improvement

\begin{tabular}{|c|c|c|c|c|c|}
\hline States & 1960s & 1970s & $1980 \mathrm{~s}$ & $1990 \mathrm{~s}$ & $2000 \mathrm{~s}$ \\
\hline Andhra Pradesh & 996 & 1,011 & 997 & 1,000 & 1,018 \\
\hline Assam & 831 & 855 & 869 & 897 & 932 \\
\hline Bihar & 884 & 897 & 894 & 878 & 867 \\
\hline Gujarat & 941 & 970 & 973 & 946 & 943 \\
\hline Haryana & 881 & 888 & 875 & 857 & 838 \\
\hline Himachal Pradesh & 947 & 943 & 1008 & 983 & 971 \\
\hline Karnataka & 954 & 957 & 970 & 964 & 966 \\
\hline Kerala & 1,025 & 1,020 & 1,025 & 1,041 & 1,075 \\
\hline Madhya Pradesh & 988 & 990 & 977 & 937 & 906 \\
\hline Maharashtra & 934 & 955 & 948 & 923 & 913 \\
\hline Odisha & 923 & 925 & 912 & 886 & 937 \\
\hline Punjab & 846 & 854 & 837 & 872 & 906 \\
\hline Rajasthan & 922 & 938 & 908 & 894 & 910 \\
\hline Tamil Nadu & 1016 & 987 & 976 & 984 & 998 \\
\hline UttarPradesh & 846 & 850 & 830 & 821 & 827 \\
\hline West Bengal & 796 & 794 & 875 & 901 & 912 \\
\hline
\end{tabular}
is marginal compared to other states. Some of the largest gains happened in the poorest states of India, the so-called 
"BIMARU" states. However, we also observe that there are significant variations in the sex ratio of the voters across the states.

In sharp contrast, in Table $2 b$, when we look at the average sex ratio of the electors we do not observe a similar pattern. As a matter of fact, there are some states for which the sex ratio of electors has marginally worsened from the 1960s to the 200os. This suggests that the increase in the sex ratio of the voters is not driven by more women registering to vote relative to men, but is, instead, driven by the fact that more women are actually casting their vote in the elections, relative to men. This is an important observation in the data.

We also plot the sex ratio of voters and electors for every state over the election years. We see that over the 50 years, the trend in the sex ratio of voters is positive for all the states, except for Haryana and TN where the voter sex ratios are nearly flat. This means that in almost all the states of India, more and more women are casting their votes in comparison to men. In sharp contrast, the trend in the electors' sex ratio for most of the states remains more or less flat with the exception of Haryana where it has declined. Given that the electors' sex ratio is a close approximation of the gender ratio in adult population of the state, the trend in electors' sex ratio reflects the trend in the adult population sex ratio of the state. Figure 1a shows the voters' sex ratio and electors' sex ratio for the traditionally backward states in India. Figure $\mathrm{lb}$ shows the voters' sex ratio and electors' sex ratio for the southern states in India and finally Figure ic (p 66) shows the voters' sex ratio and electors' sex ratio for the remaining seven large states.

Next we do a fixed effects regression analysis to study the trends in the sex ratio of voters and electors. We also do a similar fixed effects regression analysis for the female and the male poll percentage. In particular we run the following regression:

$\mathrm{Y}_{\mathrm{st}}=$ state dummies $+\beta_{1}$ post7o $+\beta_{2}$ post8o $+\beta_{3}$ post9o $+\beta_{4}$ postoo $+\varepsilon_{\text {st }}$

where $y_{s t}$ is the outcome variable of interest. The different outcomes that we will study are the following: (1) sex ratio of voters, (2) sex ratio of electors, (3) female
Figure 1a: Bihar, Madhya Pradesh, Rajasthan, Uttar Pradesh
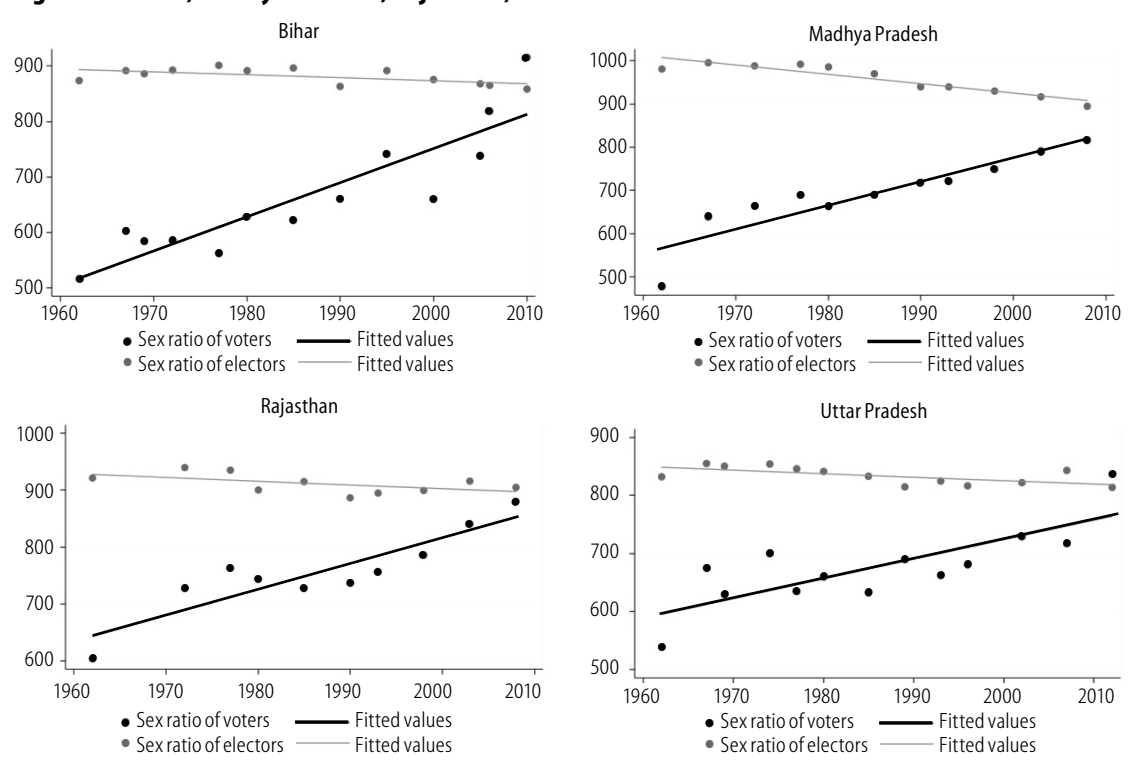

Source: Authors' calculations from ECl data.

Figure 1b: Southern States
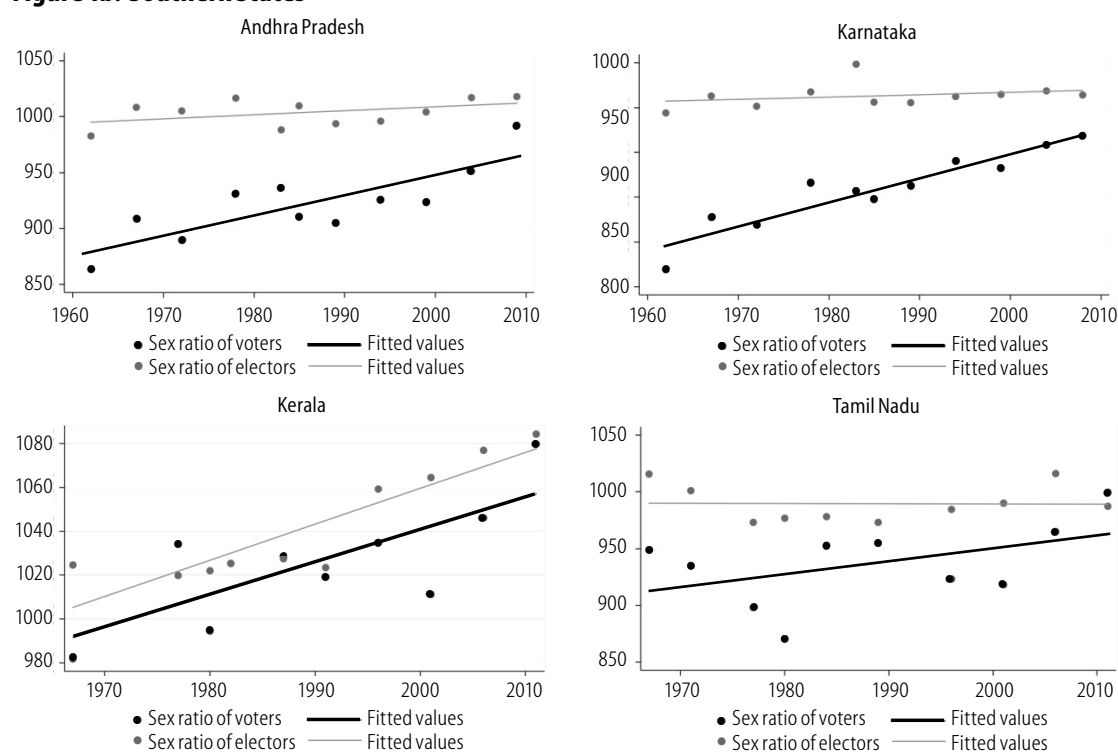

Source: Authors' calculations from ECl data.

poll percentage, and (4) male poll percentage. The subscript $s$ is the state, $t$ is the year in which the election is held for the state assembly, post7o is a dummy variable which equals 1 if the state elections are held on or after the year 1970 and before the year 1980. Similarly, post8o is a dummy variable which equals 1 if the state elections are held on or after the year 1980 and before the year 1990, postgo is a dummy variable which equals 1 if the state elections are held on or after the year 1990 and before the year 200o, postoo is a dummy variable which equals 1 if the state elections are held on or after the year 200o. $\varepsilon_{s t}$ is the error term.

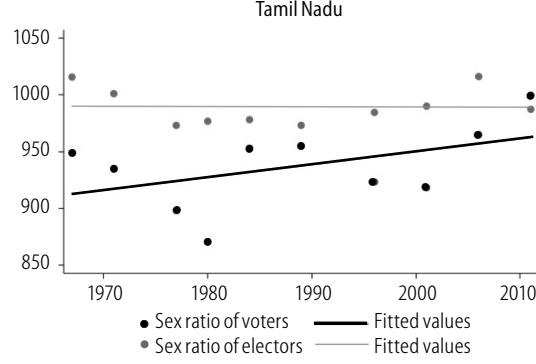

The results of our regression analysis are in Table 3 ( $\mathrm{p} \mathrm{66)}$ from column (1) to column (8). In column (1) and column (2) of the table we report the results for sex ratio of the voters with and without the state fixed effects respectively. From column (1) we note that in the 1960s the average sex ratio of the voters was 715 and it increased significantly by 168 points to 883 in the 200os. This is the key finding of this article.

The results are very similar when we control for the state fixed effects. In particular, from column (2) we see that the sex ratio of the voters has increased very significantly over time and has 


\section{Figure 1c: Remaining Large States}
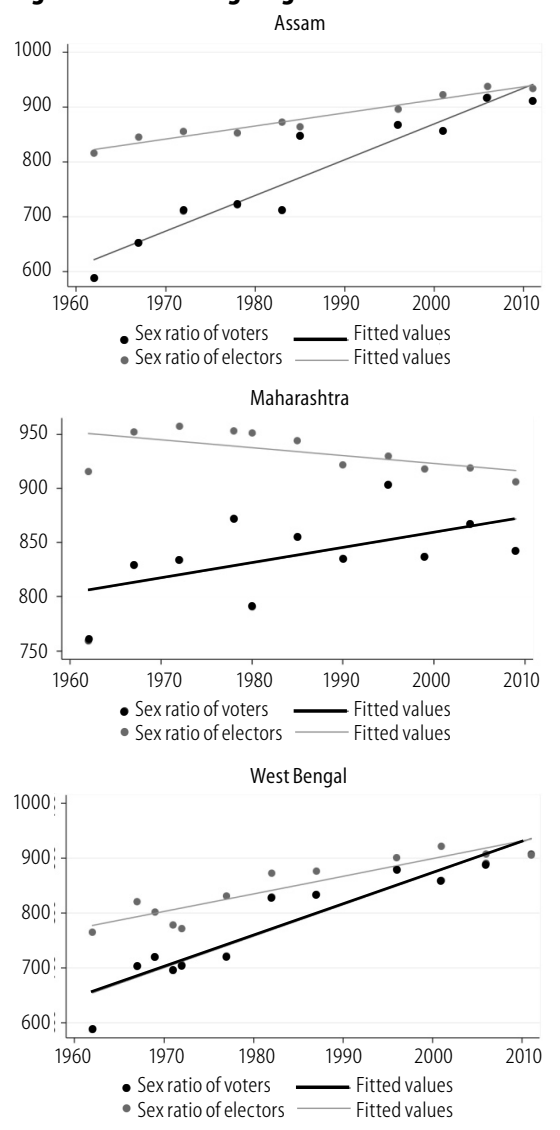

improved for every successive decade. When we compare the 1960s to the 1970s we note that the sex ratio of the voters went up by 45 , from the 1970 s to the 1980 s it improved by 28 , it further went up by 30 from the 1980 s to the 1990s and it improved dramatically by 52 when we compare the 1990s to the 20oos. These results reflect the main point of our article that gender bias in voting has declined steadily and very significantly over time.

In columns (3) and (4) we report results for the sex ratio of electors with and without the state fixed effects, respectively. We find that the sex ratio of the electors has remained more or less the same throughout the decades. This result also directly implies that an improvement in the sex ratio of voters is driven by more women actually casting their votes in elections, relative to men. And that this result is not driven by more women getting registered to vote which is reflected in the unchanging sex ratio of electors in the states over time.

We directly test this by looking at the voter turnout of women and men over 50 years. In particular, we study the
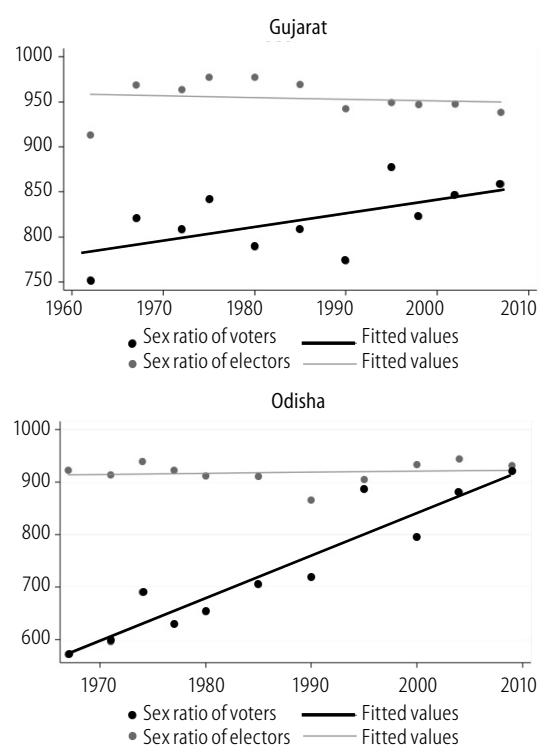

female and male poll percentage over time. Female poll percentage is defined as number of female voters who actually cast their vote to every 100 registered female electors. The results for women voter turnout or female poll percentage are reported in columns (5) and (6) with and without the state fixed effects, respectively. Our results show that over time the female poll percentage has increased very significantly and it has been increasing decade after decade steadily. The rising trend started in the 1980 s and picked up momentum in the 1990s and the 2ooos.

In sharp contrast to the rising female poll percentage, when we look at the male poll percentage or male voter turnout (results in columns (7) and (8) with and without the state fixed effects,

Table 3: Regression Analysis

\begin{tabular}{|c|c|c|c|c|c|c|c|c|}
\hline & $\begin{array}{l}\text { Sex Ratio } \\
\text { of Voters } \\
\text { (1) }\end{array}$ & $\begin{array}{l}\text { Sex Ratio } \\
\text { of Voters } \\
\text { (2) }\end{array}$ & $\begin{array}{l}\text { Sex Ratio } \\
\text { of Electors } \\
\text { (3) }\end{array}$ & $\begin{array}{cc}\text { SexRatio } & \text { Fe } \\
\text { of Electors } & P \\
\text { (4) }\end{array}$ & $\begin{array}{l}\text { Female Poll } \\
\text { Percentage } \\
\text { (5) }\end{array}$ & $\begin{array}{l}\text { Female Poll } \\
\text { Percentage } \\
\text { (6) }\end{array}$ & $\begin{array}{l}\text { Male Poll } \\
\text { Percentage } \\
\text { (7) }\end{array}$ & $\begin{array}{l}\text { Male Poll } \\
\text { Percentage } \\
\text { (8) }\end{array}$ \\
\hline post70 & $\begin{array}{l}53.6^{*} \\
(30.1)\end{array}$ & $\begin{array}{l}4^{45.1^{* * * *}} \\
(15.7)\end{array}$ & $\begin{array}{r}17.1 \\
(16.9)\end{array}$ & $\begin{array}{r}7.88 \\
(7.13) \\
\end{array}$ & $\begin{array}{r}1.80 \\
(2.95)\end{array}$ & $\begin{array}{r}1.59 \\
(1.93)\end{array}$ & $\begin{array}{r}-1.11 \\
(1.66)\end{array}$ & $\begin{array}{r}-1.27 \\
(1.46)\end{array}$ \\
\hline post80 & $\begin{array}{l}100.3^{* * *} \\
(30.1)\end{array}$ & $\begin{array}{l}73.1^{* * *} \\
(14.7)\end{array}$ & $\begin{array}{l}30.5^{*} \\
(16.2)\end{array}$ & $\begin{array}{r}9.68 \\
(6.05) \\
\end{array}$ & $\begin{array}{r}5.19 \\
(3.18) \\
\end{array}$ & $\begin{array}{r}3.96^{*} \\
(2.06)\end{array}$ & $\begin{array}{l}-0.18 \\
(2.01)\end{array}$ & $\begin{array}{l}-0.89 \\
(1.67)\end{array}$ \\
\hline post90 & $\begin{array}{l}119.0^{* * *} \\
(29.5) \\
\end{array}$ & $\begin{array}{l}104.0^{* * *} \\
(16.5)\end{array}$ & $\begin{array}{r}24.4 \\
(15.9) \\
\end{array}$ & $\begin{array}{r}2.01 \\
(6.31) \\
\end{array}$ & $\begin{array}{l}8.05^{* * *} \\
(3.01)\end{array}$ & $\begin{array}{l}8.80^{* * *} \\
(2.54) \\
\end{array}$ & $\begin{array}{r}1.50 \\
(1.99) \\
\end{array}$ & $\begin{array}{r}1.97 \\
(2.05) \\
\end{array}$ \\
\hline post00 & $\begin{array}{l}168.0^{* * *} \\
(27.2)\end{array}$ & $\begin{array}{l}156.4^{* * *} \\
(16.4)\end{array}$ & $\begin{array}{r}25.2 \\
(16.1) \\
\end{array}$ & $\begin{array}{l}16.0^{* *} \\
(7.43)\end{array}$ & $\begin{array}{l}12.7^{* * *} \\
(2.73) \\
\end{array}$ & $\begin{array}{l}12.1^{* * *} \\
(1.88)\end{array}$ & $\begin{array}{r}2.81 \\
(1.77) \\
\end{array}$ & $\begin{array}{c}2.45^{*} \\
(1.45) \\
\end{array}$ \\
\hline Constant & $\begin{array}{l}715.1^{* * *} \\
(23.2)\end{array}$ & $\begin{array}{l}846.2^{* * *} \\
(15.7)\end{array}$ & $\begin{array}{l}903.2^{* * *} \\
(12.4)\end{array}$ & $\begin{array}{l}996.4^{* * *} \\
(5.65)\end{array}$ & $\begin{array}{c}* 52.7^{* * *} \\
(2.23) \\
\end{array}$ & $\begin{array}{l}60.5^{* * *} \\
(1.88) \\
\end{array}$ & $\begin{array}{l}65.8^{* * *} \\
(1.15)\end{array}$ & $\begin{array}{c}* 71.1^{* * *} \\
(1.44) \\
\end{array}$ \\
\hline State fixed effects & $\mathrm{N}$ & $Y$ & $\mathrm{~N}$ & $Y$ & $\mathrm{~N}$ & $Y$ & $\mathrm{~N}$ & $Y$ \\
\hline$\overline{A d j-R^{2}}$ & 0.218 & 0.823 & 0.025 & 0.850 & 0.135 & 0.615 & 0.028 & 0.390 \\
\hline bserva & 176 & 76 & 176 & 176 & 176 & 176 & 176 & 176 \\
\hline
\end{tabular}

Standard errors in parentheses, ${ }^{*} p<0.10^{* *} p<0.05^{* * *} p<0.01$.

post70 is a dummy variable which equals 1 if the state elections are held on or after the year 1970 and before the year 1980 and 0 otherwise, post 80 is a dummy variable which equals 1 if the state elections are held on or after the year 1980 and before the year 1990 and 0 otherwise, post 90 is a dummy variable which equals 1 if the state elections are held on or after the year 1990 and before the year 2000 and 0 otherwise, post00 is a dummy variable which equals 1 if the state elections are held on or after the year 2000 and 0 otherwise.
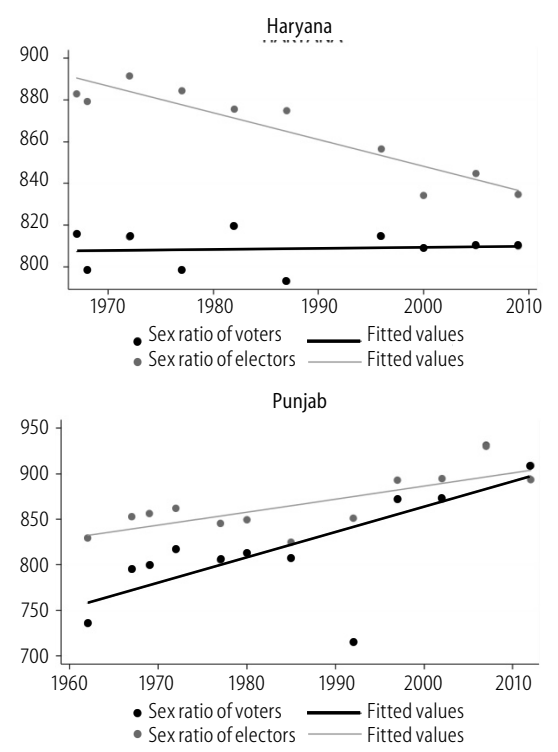

respectively) we do not observe a similar pattern. In fact the male poll percentage has remained stable through the decades while increasing only marginally in the 200os, however, and it is not significant at the conventional $5 \%$ level of statistical significance. This result confirms that more women relative to men are turning out to vote in the elections. This voluntary act of self-empowerment is the key driving force in reducing the gender bias in voting amongst Indians over the last five decades.

Next, we are curious to see whether this positive national phenomenon of rising female voter participation also holds in the states which have been traditionally considered backward in India. For this, we repeat the same regression 
Table 4: Regression Analysis for the "BIMARU" States

\begin{tabular}{|c|c|c|c|c|c|c|c|c|}
\hline & $\begin{array}{l}\text { Sex Ratio } \\
\text { of Voters } \\
\text { (1) }\end{array}$ & $\begin{array}{l}\text { Sex Ratio } \\
\text { of Voters } \\
\text { (2) }\end{array}$ & $\begin{array}{c}\text { SexRatio } \\
\text { of Electors } \\
(3)\end{array}$ & $\begin{array}{cc}\text { Sex Ratio } & F \\
\text { of Electors } & P \\
(4) & \end{array}$ & $\begin{array}{l}\text { Female Poll Fe } \\
\text { Percentage Pe } \\
\text { (5) }\end{array}$ & $\begin{array}{l}\text { Female Poll } \\
\text { Percentage } \\
(6) \\
\end{array}$ & $\begin{array}{l}\text { Male Poll } \\
\text { Percentage } \\
(7)\end{array}$ & $\begin{array}{c}\text { Male Poll } \\
\text { Percentage } \\
(8)\end{array}$ \\
\hline post70 & $\begin{array}{l}80.6^{* *} \\
(32.0)\end{array}$ & $\begin{array}{l}68.8^{* *} \\
(27.8) \\
\end{array}$ & $\begin{array}{r}20.0 \\
(27.0) \\
\end{array}$ & $\begin{array}{r}9.59 \\
(5.74) \\
\end{array}$ & $\begin{array}{l}4.55^{*} \\
(2.59) \\
\end{array}$ & $\begin{array}{r}3.65 \\
(2.52) \\
\end{array}$ & $\begin{array}{r}0.41 \\
(1.75) \\
\end{array}$ & $\begin{array}{c}-0.31 \\
(1.75) \\
\end{array}$ \\
\hline post80 & $\begin{array}{l}87.8^{* * * *} \\
(25.5) \\
\end{array}$ & $\begin{array}{l}77.8^{* * *} \\
(24.2)\end{array}$ & $\begin{array}{r}-4.33 \\
(27.1) \\
\end{array}$ & $\begin{array}{r}-7.77 \\
(6.78) \\
\end{array}$ & $\begin{array}{r}3.63 \\
(2.32) \\
\end{array}$ & $\begin{array}{r}2.84 \\
(2.53) \\
\end{array}$ & $\begin{array}{l}-3.04 \\
(2.14) \\
\end{array}$ & $\begin{array}{r}-3.31 \\
(2.22) \\
\end{array}$ \\
\hline post90 & $\begin{array}{l}136.4^{* * *} \\
(24.9)\end{array}$ & $\begin{array}{l}119.3^{* * *} \\
(26.2)\end{array}$ & $\begin{array}{r}-9.75 \\
(23.4) \\
\end{array}$ & $\begin{array}{l}-27.9^{* * *} \\
(6.23)\end{array}$ & $\begin{array}{l}12.8^{* * * *} \\
(2.22)\end{array}$ & $\begin{array}{c}* 11.5^{* * * *} \\
(2.47)\end{array}$ & $\begin{array}{l}4.00^{* * *} \\
(1.39)\end{array}$ & $\begin{array}{r}2.81 \\
(1.73) \\
\end{array}$ \\
\hline post00 & $\begin{array}{l}209.8^{* * *} \\
(31.4)\end{array}$ & $\begin{array}{l}206.2^{* * *} \\
(31.5)\end{array}$ & $\begin{array}{r}-27.8 \\
(21.7) \\
\end{array}$ & $\begin{array}{l}-29.9^{* * *} \\
(8.08)\end{array}$ & $\begin{array}{l}15.0^{* * * *} \\
(3.41)\end{array}$ & $\begin{array}{c}* 14.7^{* * *} \\
(3.24)\end{array}$ & $\begin{array}{r}-0.59 \\
(3.22) \\
\end{array}$ & $\begin{array}{l}-0.85 \\
(2.98) \\
\end{array}$ \\
\hline Constant & $\begin{array}{l}585.0^{* * *} \\
(21.0)\end{array}$ & $\begin{array}{c}596.2^{* * *} \\
(30.1) \\
\end{array}$ & $\begin{array}{l}898.6^{* * *} \\
(18.9)\end{array}$ & $\begin{array}{l}970.1^{* * * *} \\
(8.03)\end{array}$ & $\begin{array}{l}40.0^{* * * *} \\
(1.94)\end{array}$ & $\begin{array}{c}* 40.3^{* * *} \\
(2.97)\end{array}$ & $\begin{array}{l}61.0^{* * *} \\
(0.93)\end{array}$ & $\begin{array}{l}64.6^{* * *} \\
(1.91)\end{array}$ \\
\hline State fixed effects & $\mathrm{N}$ & $Y$ & $\mathrm{~N}$ & $Y$ & $\mathrm{~N}$ & $Y$ & $\mathrm{~N}$ & $Y$ \\
\hline Adj-R $R^{2}$ & 0.604 & 0.725 & 0.097 & 0.925 & 0.516 & 0.610 & 0.135 & 0.319 \\
\hline Observations & 47 & 47 & 47 & 47 & 47 & 47 & 47 & 47 \\
\hline
\end{tabular}

Standard errors in parentheses, ${ }^{*} p<0.10 * * p<0.05 * * * p<0.01$.

post70 is a dummy variable which equals 1 if the state elections are held on or after the year 1970 and before the year 1980 and 0 otherwise, post 80 is a dummy variable which equals 1 if the state elections are held on or after the year 1980 and before the year 1990 and 0 otherwise, post90 is a dummy variable which equals 1 if the state elections are held on or after the year 1990 and before the year 2000 and 0 otherwise, post00 is a dummy variable which equals 1 if the state elections are held on or after the year 2000 and 0 otherwise.

analysis as above on a restricted sample by only considering the "BIMARu" states. Our results are similar to the previous analysis and we find that this positive movement is also seen amongst the poorer and backward states.

In particular, we find that in the "BIMARU" states the gender bias has declined very dramatically over time. Once again, consistent with the previous results from the national sample, even in these states the reducing gender gap is driven by more women relative to men turning out to vote in the assembly elections. In fact, when we compare the gender ratio of electors in these backward states, we actually see a decline post 1990 (column 4). However, this decline in the sex ratio of registered electors is more than compensated by a dramatic increase in the sex ratio of voters during this period. That is, more and more women voters actually cast their votes in the elections. This is reflected in the improving female poll percentage (column 6) as compared to an unchanging male poll percentage (column 8) over time.

The data has conclusively shown that over time, the increase in the female voter turnout is significant in all the 16 states of India. This is the key phenomenon that we want to highlight in this article.

\section{Discussion and Conclusions}

There is a vast literature in politics which establishes the necessity of universal suffrage for representative democracy. And yet, while advocating universal suffrage, James Mill had argued that in order to keep expense of representative system down, women need not have separate voting rights because their interests were included within those of their husbands and fathers (Ryan 2012). We study the data on Indian elections over the last 50 years and explore the increasing significance of women voters in a democracy. We find that systematically the gender bias in voting is being reduced, over time and across all states of India. Voluntarily, more and more women electors are actually casting their votes. We interpret these results as a testimony to self-empowerment of women voters in Indian democracy.

Previous research on female empowerment have analysed varying outcomes of interest. Some of these include intrahousehold decision-making (Ashraf 2009), leadership in politics (Beaman et al 2009; Chattopadhyay et al 2004), access to finance (De Mel et al 2009), and seeking healthcare (Rai and Ravi 2011). This article contributes to the existing literature on female empowerment by analysing the role of women as voters.

Existing research has shown persistent gender inequality in outcomes including health, education, labour force participation and political representation. Perhaps for the first time, we discover a significant and persistent reduction in gender inequality when we analyse voter turnout in all state elections in India, over the past 50 years. We compare the turnout of women voters to men in all state elections from 1962 till 2012. Our analysis reveals a sharp decline in gender bias in voting over time, across all states, including the traditionally backward states. This decline is solely driven by an increase in women participation while male turnout remains unchanged over time. This is a positive and encouraging trend in Indian politics. Particularly, as this improvement does not seem to be brought about by a deliberate top-down policy action but largely due to voluntary participation of women voters in elections, that is the reason, we term this phenomenon as one of self-empowerment.

\section{REFERENCES}

Anderson, Siwan and Debraj Ray (2010): "Missing Women: Age and Disease", The Review of Economic Studies, 77: 1262-1300.

Ashraf, Nava (2009): "Spousal Control and Intrahousehold Decision Making: An Experimental Study in the Philippines", American Economic Review, 99(4): 1245-77.

Beaman, Lori, Raghabendra Chattopadhyay, Esther Duflo, Rohini Pande and Petia Topalova (2009): "Powerful Women: Does Exposure Reduce Bias?", Quarterly Journal of Economics, 124 (4): 1497-1540.

Brender, Adi and Allan Drazen (2008): "How Do Budget Deficits and Economic Growth Affect Reelection Prospects? Evidence from a Large Panel of Countries", American Economic Review, 98(5): 2203-20.

Chattopadhyay, Raghabendra and Esther Duflo (2004): "Women as Policy Makers: Evidence from a Randomised Policy Experiment in India", Econometrica, 72(5): 1409-43.

De Mel, Suresh, David McKenzie and Christopher Woodruff (2009): "Are Women More Credit Constrained? Experimental Evidence on Gender and Microenterprise Returns", American Economic Journal: Applied Economics, 1(3): 1-32.

Duflo, Esther (2012): "Women Empowerment and Economic Development", Journal of Economic Literature, 50(4): 1051-79.

Dutta, Bhaskar and Poonam Gupta (2012): "How Indian Voters Respond to Candidates with Criminal Charges: Evidence from the 2009 Lok Sabha Elections", Working Paper No 2012-109, NIPFP, New Delhi

Election Commission of India Database, 1962-2012. Gupta, Poonam and Arvind Panagariya (2012): "India: Election Outcomes and Economic Performance", Working Paper No 2011-4, Academic Commons, Columbia University.

Iyer, Lakshmi, Anandi Mani, Prachi Mishra and Petia Topalova (2012): "The Power of Political Voice: Women's Political Representation and Crime in India", American Economic Journal: Applied Economics, 4(4): 165-93.

Rai, Ashok and Shamika Ravi (2011): "Do Spouses Make Claims? Empowerment and Microfinance in India", World Development, 39(6): 913-21.

Ryan, Alan (2012): On Politics: A History of Political Thought from Herodotus to the Present (Allen Lane Publications).

Sen, Amartya (1990): "More Than 100 Million Women Are Missing", The New York Review of Books, 37(20).

- (1992). "Missing Women", British Medical Journal, 304: 587-88. 